\title{
Diagnostic Interpretation Guidance for Pediatric Enteric Pathogens: A Modified Delphi Consensus Process
}

\author{
Antonia S. Stang $\mathbb{D}^{1},{ }^{1}$ Melanie Trudeau, ${ }^{2}$ Otto G. Vanderkooi, ${ }^{3}$ Bonita E. Lee, ${ }^{4}$ Linda Chui, ${ }^{5,6}$ \\ Xiao-Li Pang, ${ }^{5,6}$ Vanessa Allen, ${ }^{7,8}$ Carey-Ann D. Burnham, ${ }^{9}$ David M. Goldfarb, ${ }^{10,11}$ \\ Judy MacDonald, ${ }^{12}$ Brendon Parsons, ${ }^{5}$ Astrid Petrich, ${ }^{8,13}$ Frank Pollari, ${ }^{14}$ Phillip I. Tarr, ${ }^{15}$ \\ Graham Tipples, ${ }^{5,6}$ Ran Zhuo, ${ }^{5}$ and Stephen B. Freedman $\mathbb{D}^{16,17}$ \\ ${ }^{1}$ Departments of Pediatrics, Emergency Medicine and Community Health Sciences, University of Calgary, \\ Alberta Children's Hospital Research Institute, Calgary, Alberta, Canada \\ ${ }^{2}$ Department of Pediatrics, University of Calgary, Calgary, Alberta, Canada \\ ${ }^{3}$ Departments of Pediatrics, Microbiology, Immunology and Infectious Diseases, Pathology \& Laboratory Medicine and \\ Community Health Sciences, University of Calgary, Alberta Children's Hospital Research Institute, Calgary, Alberta, Canada \\ ${ }^{4}$ Department of Pediatrics, University of Alberta, Edmonton, Alberta, Canada \\ ${ }^{5}$ Department of Laboratory Medicine and Pathology, University of Alberta, Edmonton, Alberta, Canada \\ ${ }^{6}$ Alberta Provincial Laboratory for Public Health, Edmonton, Alberta, Canada \\ ${ }^{7}$ Public Health Ontario Laboratories, University of Toronto, Toronto, Ontario, Canada \\ ${ }^{8}$ Department of Laboratory Medicine and Pathobiology, University of Toronto, Toronto, Ontario, Canada \\ ${ }^{9}$ Departments of Pathology \& Immunology, Molecular Microbiology, and Pediatrics, \\ Washington University in St. Louis School of Medicine, St. Louis, MO, USA \\ ${ }^{10}$ Department of Pathology and Laboratory Medicine, BC Children's Hospital, Vancouver, British Columbia, Canada \\ ${ }^{11}$ University of British Columbia, Vancouver, British Columbia, Canada \\ ${ }^{12}$ Population, Public and Indigenous Health, Cumming School of Medicine, University of Calgary, Calgary, Alberta, Canada \\ ${ }^{13}$ Department of Paediatric Laboratory Medicine, The Hospital for Sick Children, Toronto, Ontario, Canada \\ ${ }^{14}$ Enterics Surveillance and Population Studies Division, Centre for Food-Borne, Environmental and Zoonotic Infectious Diseases, \\ Public Health Agency of Canada, Guelph, Ontario, Canada \\ ${ }^{15}$ Division of Gastroenterology, Hepatology, and Nutrition, Department of Pediatrics, Washington University School of Medicine, \\ St. Louis, MO, USA \\ ${ }^{16}$ Sections of Pediatric Emergency Medicine and Gastroenterology, Departments of Pediatrics, University of Calgary, \\ Alberta Children's Hospital, Calgary, Alberta, Canada \\ ${ }^{17}$ Alberta Children's Hospital Research Institute, Cumming School of Medicine, Calgary, Alberta, Canada
}

Correspondence should be addressed to Antonia S. Stang; antonia.stang@albertahealthservices.ca and Stephen B. Freedman; stephen.freedman@albertahealthservices.ca

Received 1 June 2018; Accepted 7 August 2018; Published 27 September 2018

Academic Editor: Maria De Francesco

Copyright (c) 2018 Antonia S. Stang et al. This is an open access article distributed under the Creative Commons Attribution License, which permits unrestricted use, distribution, and reproduction in any medium, provided the original work is properly cited.

Background. We sought to develop diagnostic test guidance definitions for pediatric enteric infections to facilitate the interpretation of positive test results in the era of multianalyte molecular diagnostic test platforms. Methods. We employed a systematic, two-phase, modified Delphi consensus process consisting of three web-based surveys and an expert panel face-toface meeting. In phase 1, we surveyed an advisory panel of North American experts to select pathogens requiring diagnostic test guidance definition development. In phase 2, we convened a 14-member expert panel to develop, refine, and select the final definitions through two web-based questionnaires interspersed with a face-to-face meeting. Both questionnaires asked panelists to rate the degree to which they agreed that if the definition is met the pathogen is likely to be causative of clinical illness. Results. The advisory panel survey identified 19 pathogens requiring definitions. In the expert panel premeeting survey, 13 of the 19 definitions 
evaluated were rated as being highly likely ("agree" or "strongly agree") to be responsible for acute gastroenteritis symptoms by $\geq 67 \%$ of respondent panel members. The definitions for the remaining six pathogens (Aeromonas, Clostridium difficile, Edwardsiella, nonenteric adenovirus, astrovirus, and Entamoeba histolytica) were indeterminate. After the expert panel meeting, only two of the modified definitions, C. difficile and E. histolytica/dispar, failed to achieve the a priori specified threshold of $\geq 67 \%$ agreement. Conclusions. We developed diagnostic test guidance definitions to assist healthcare providers for 17 enteric pathogens. We identified two pathogens that require further research and definition development.

\section{Introduction}

Diarrheal disease is the second leading cause of child mortality worldwide $[1,2]$ and is among the most common causes of illness globally, with over 4 billion episodes occurring annually [3-5]. In the United States, there are 178.8 million episodes of diarrhea contributing to 473,832 hospitalizations each year [6]. Infection by a variety of gastrointestinal pathogens, including parasites, bacteria, and viruses, can cause vomiting and diarrhea that typifies acute gastroenteritis. Multiple diagnostic testing methods are available to identify enteric pathogens including traditional culture techniques for enteric bacteria, direct microscopy for parasites, enzyme immunoassay (EIA) for select enteric viruses, bacterial toxins and some parasites, and molecular methods for specific targets. Despite the availability of multiple modalities to identify enteric pathogens, the etiology often remains unidentified. However, recent practice changes including the collection of rectal swabs rather than stool specimens [7-9] to increase specimen acquisition rates, and the increasing use of molecular methods, especially syndromic panels which detect multiple pathogens simultaneously [10-12] have significantly increased the detection rates of enteric pathogens in symptomatic individuals [13].

Existing guidelines on the diagnosis [14] and management [15] of enteric infectious diseases do not adequately consider the implications of recent advances in sample collection or molecular diagnostic techniques. For example, recently published adult guidelines by the American College of Gastroenterology suggest that the best applicability for molecular diagnostic tests is for the clinician in practice, but do not provide guidance on how clinicians should interpret the results of such testing [16]. The implementation of commercial multiplex gastrointestinal pathogen panels presents practical challenges to healthcare providers in assessing the clinical relevance of positive results and to public health officials who are responsible for surveillance and follow-up of reportable infectious agents. Positive results generated by molecular assays cannot distinguish between asymptomatic carriage, subclinical infection, active disease, resolved disease, or the presence of target nucleic acids liberated by nonpathogens [16]. High rates of enteric pathogen detection have been reported in asymptomatic children [17]. Commercially available multianalyte panels also identify organisms that were not previously routinely tested for such as non-O157 Shiga toxin-producing Escherichia coli (STEC). These challenges highlight the need for the use of standardized definitions to guide the interpretation of multiplex polymerase chain reaction (PCR) results by clinicians who often have limited knowledge of laboratory testing procedures. While definitions do exist for some enteric pathogens in the context of public health and outbreak management, no specific definitions exist to guide interpretation and management by healthcare providers. The latter are important because accurate diagnosis by frontline clinicians is crucial to identify those patients who would benefit from antimicrobial therapy and those where unnecessary antibiotics may cause harm [15].

Given the existing knowledge gap, and the paucity of high-quality evidence supporting the clinical interpretation of multianalyte molecular diagnostic test platforms, we conducted a modified Delphi consensus process to develop provisional diagnostic test guidance definitions for pediatric enteric infections to guide the interpretation, by clinicians, of positive diagnostic test results. The goal was to provide guidance for clinicians providing care to children up to 18 years of age with symptoms of acute gastroenteritis defined as a decrease in stool consistency and/or by the presence of three or more episodes of stool or vomiting in a 24-hour period with duration of symptoms of less than seven days $[18,19]$.

\section{Materials and Methods}

The approach consisted of a systematic, two-phase, modified Delphi consensus methodology with three web-based surveys and an expert panel face-to-face meeting [20]. Ethics approval for this study was obtained by the Conjoint Health Research Ethics Board of the University of Calgary.

\subsection{Phase 1: Selection of Pathogens Requiring Diagnostic Test} Guidance Definition Development. An advisory panel was convened to (1) identify pathogens that require further definition development and (2) select diagnostic tests including culture, electron microscopy (EM), PCR and EIA, and specimen types (i.e., stool, oral, and rectal swabs [21]), which, if positive, would fulfill the definition for each agent. The advisory panel consisted of pediatricians, pediatric emergency medicine and infectious diseases physicians, gastroenterologists, medical microbiologists, and experts in virology and laboratory medicine. Selection criteria for panel members included interest or expertise in pediatric enteric infections as demonstrated by publications in the field, experience in infectious diseases, geographic and practice diversity, and balance between individuals with clinical and laboratory expertise. Candidate panel members received a written invitation to participate that contained a description of study goals, responsibilities, and timelines. 
Candidate advisory panel members received a web-based survey managed in REDCap [22] in which they were asked to (1) rate the degree to which they agreed, on a scale of 1disagree strongly to 5-agree strongly, that a positive result for each of pathogen/diagnostic test/sample collection methods is causative of the child's symptoms. It was determined a priori that any pathogen which was unanimously rated as "agree strongly" for all diagnostic test/sample collection modalities would be removed from further consideration as unanimous agreement would indicate that further definition is not required. All other pathogens were retained for further definition development. Free text comments were permitted.

We assessed a list of 19 agents (11 bacteria, 5 viruses, and 3 parasites) that were included in the diagnostic testing panels being evaluated as part of the APPETITE (Alberta Provincial Pediatric EnTeric Infection TEam) project [7]. APPETITE is a provincial initiative designed to comprehensively understand the epidemiology of acute pediatric enteric infections employing rectal swabs and stool samples and a comprehensive diagnostic testing approach.

\subsection{Phase 2: Development of Diagnostic Test Guidance} Definitions. The study team identified existing definitions for each pathogen retained from phase 1 based on a review of Canada's provincial public health case definitions. For pathogens with no existing syndromic-based definitions, the study team developed candidate definitions based on the results of the advisory panel survey in phase 1 .

2.3. Expert Panel. We convened an expert panel to refine and select the final definitions. The expert panel consisted of individuals trained in pediatrics, infectious diseases, public health, gastroenterology, medical microbiology, virology, and laboratory medicine. Panelists were selected by study investigators from the initial advisory panel and based on recommendations from APPETITE's International Scientific Advisory Committees [7]. Selection criteria included interest or expertise in pediatric enteric infections, clinical decision making experience, geographic and practice diversity, and publications.

A description of research project goals, a summary of the advisory panel survey results, and the existing and newly developed evidence-based definitions were sent to expert panel members. A modified Delphi technique consisting of two rounds of anonymous questionnaires, and a face-to-face meeting was used to generate final study definitions.

2.3.1. Expert Panel Survey 1. The first web-based questionnaire asked panelists to rate the degree to which they agreed that if the definition is met, in a child with vomiting and/or diarrhea, the pathogen is likely to be the cause of the illness. All definitions were specified to be in the context of (1) clinical illness with acute gastroenteritis defined as a decrease in stool consistency and/or by the presence of three or more episodes of loose stool or vomiting in a 24hour period with a duration of symptoms less than seven days and (2) a positive laboratory diagnostic test for a single pathogen (i.e., no codetection). Specimens considered included stool as well as oral [23] and rectal swabs. Panelists were asked to rate each definition employing a Likert scale ranging from 1 (strongly disagree) to 5 (strongly agree). An option was provided to suggest additional or alternate definitions.

2.3.2. Face-to-Face Meeting. After completion of the first survey, an expert panel face-to-face meeting was convened in Edmonton, Alberta, on March 4, 2016. At the meeting, panelists reviewed anonymized ratings of all the definitions. It was determined a priori that unanimously highly rated definitions (i.e., those rated "agree" or "agree strongly" by all respondents) would be retained, and unanimously low rated definitions (i.e., rated "disagree strongly" or "disagree" by all respondents) would be discarded and not discussed further. Panelists were asked to refine highly scored definitions (i.e., $\geq 67 \%$ of panelists rated "agree" or "strongly agree") and to discuss the remaining definitions.

2.3.3. Expert Panel Survey 2. After the face-to-face meeting, expert panel members received a final survey requesting that they independently re-rate each of the refined definition using the same rating scale. Definitions rated "agree" or "strongly agree" by $\geq 67 \%$ of panelists were retained in the final list of definitions. The threshold for retention was determined a priori by the expert panel at the outset of the expert panel meeting and has been previously used with such methods [24]. Pathogens for which a consensus definition could not be reached (i.e., further research required) were identified.

\section{Results}

3.1. Phase 1. Modified Delphi consensus process used to develop diagnostic test guidance definitions for pediatric enteric diseases is shown in Figure 1.

The advisory panel web-based survey was initially distributed to 88 individuals on March 26, 2015, with two follow-up e-mail reminders. Thirty-seven of 88 invited experts $(42 \%)$ completed the advisory panel survey. The majority $(89 \% ; 33 / 37)$ of respondents were $\geq 40$ years of age and practiced in Canada $(76 \% ; 28 / 37)$; the remaining $24 \%(9 / 37)$ were from the United States. The majority of the Canadian participants were from Alberta $(52 \% ; 14 / 27)$. Other provinces and territories represented included British Columbia, Northwest Territories, Nova Scotia, Ontario, and Quebec. Advisory panel participants included individuals with expertise in medical microbiology, pediatric infectious disease, pediatric emergency medicine, community and public health, and laboratory medicine (see Supplemental Table 1). Respondents were similar to nonrespondents with respect to specialty and geographic location.

No pathogen-test method had unanimous agreement (i.e., rated "strongly agree" by all) in terms of assigning causality of symptoms in a child with acute gastroenteritis (Table 1). Consequently, all 19 pathogens were considered to 


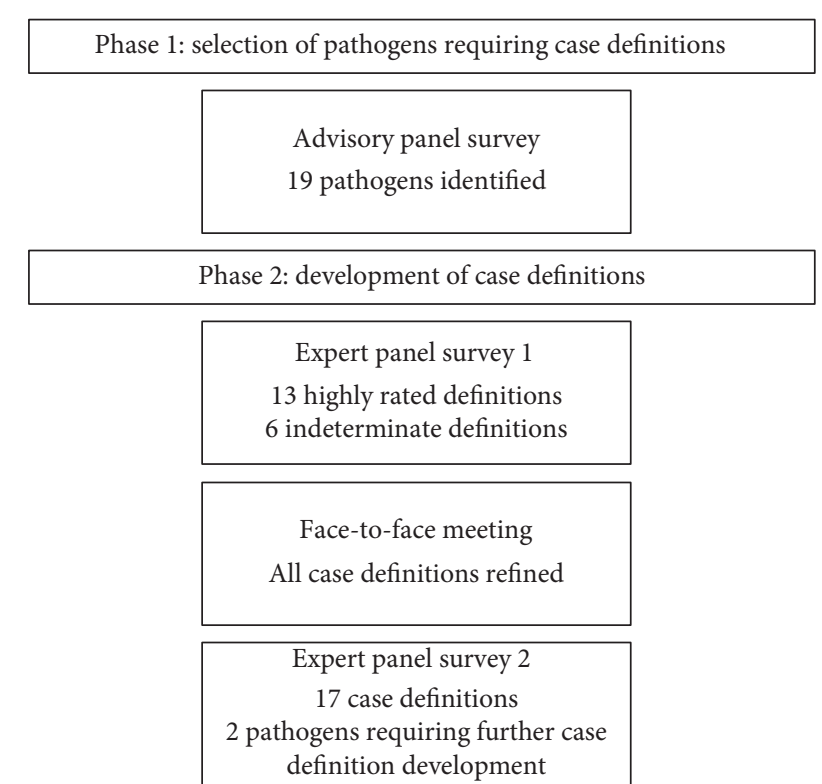

Figure 1: Modified Delphi consensus process.

require definition development. For bacterial pathogens, the median proportion agreeing with causality (i.e., rated "agree" or "strongly agree") was higher for stool culture (90\%) compared with stool PCR (83\%) and oral swab PCR (30\%). The bacterial pathogen with the lowest percent endorsement by both culture (40\%; 95\% CI: 23, 59) and PCR (30\%; 95\% CI: 15, 50) was Edwardsiella. Aeromonas and Clostridium difficile also generated $<50 \%$ agreement as to likelihood of being etiologic when identified. Viral pathogens identified by stool PCR had high levels of agreement as likely being the cause of the symptoms (range: 75-97\%) with the exception of general adenovirus which was associated as etiologic by only $51 \%$ of respondents ( $95 \%$ CI: $34 \%, 68 \%$ ). All positive results on stool evaluated for parasites were endorsed by over $50 \%$ of study participants.

\subsection{Phase 2}

3.2.1. Expert Panel: Premeeting Survey. Fourteen of 17 (82\%) individuals invited to participate in the in-person expert panel process completed a premeeting definition survey (Supplemental Table 2). The survey was distributed on January 22, 2016, with an e-mail reminder one week later (Table 2). Thirteen of the 19 definitions evaluated were rated as being highly likely ("agree" or "strongly agree") to be responsible for acute gastroenteritis symptoms by $\geq 67 \%$ of respondent panel members. The definitions for the remaining six agents (Aeromonas, C. difficile, Edwardsiella, nonenteric adenovirus, astrovirus, and Entamoeba histolytica) were indeterminate. The lowest rated bacterial pathogen was C. difficile (36\%; 95\% CI: 14, 64) while Escherichia coli O157: H7 was the only pathogen classified as etiologic by $100 \%$ of respondents. Adenovirus was the lowest rated (36\%; 95\% CI: 14, 64) viral pathogen while norovirus was the only pathogen classified as etiologic by $100 \%$ of respondents.
TABLE 1: Results from initial advisory panel survey reporting respondents who rated "agree" or "strongly agree" that the pathogen/test/collection modality was causative of symptoms in a child with acute gastroenteritis.

\begin{tabular}{|c|c|c|}
\hline Pathogen diagnostic test & $\begin{array}{c}\text { Proportion } \\
\text { agreement } \\
N(\%)\end{array}$ & $\begin{array}{c}95 \% \text { confidence } \\
\text { interval }\end{array}$ \\
\hline \multicolumn{3}{|l|}{ Bacterial pathogens } \\
\hline \multicolumn{3}{|l|}{ Aeromonas } \\
\hline Stool culture & 43 & 26,62 \\
\hline Stool PCR & 37 & 21,56 \\
\hline Oral swab PCR & 13 & 4,32 \\
\hline \multicolumn{3}{|l|}{ Campylobacter } \\
\hline Stool culture & 97 & 81,100 \\
\hline Stool PCR & 83 & 65,94 \\
\hline Oral swab PCR & 30 & 15,50 \\
\hline \multicolumn{3}{|c|}{ Clostridium difficile antigen } \\
\hline Stool EIA & 50 & 32,68 \\
\hline Stool PCR & 47 & 29,65 \\
\hline Oral swab PCR & 17 & 6,35 \\
\hline \multicolumn{3}{|l|}{ Edwardsiella } \\
\hline Stool culture & 40 & 23,59 \\
\hline Stool PCR & 30 & 15,50 \\
\hline Oral swab PCR & 17 & 6,35 \\
\hline \multicolumn{3}{|l|}{ Escherichia coli $\mathrm{O} 157$} \\
\hline Stool culture & 97 & 81,100 \\
\hline Stool PCR & 87 & 68,96 \\
\hline Oral swab PCR & 37 & 21,56 \\
\hline \multicolumn{3}{|c|}{ Enterotoxigenic Escherichia coli (ETEC) } \\
\hline Stool culture & 90 & 73,97 \\
\hline Stool PCR & 84 & 66,94 \\
\hline Oral swab PCR & 29 & 15,48 \\
\hline \multicolumn{3}{|l|}{ Salmonella spp. } \\
\hline Stool culture & 81 & 62,92 \\
\hline Stool PCR & 77 & 57,89 \\
\hline Oral swab PCR & 20 & 8,39 \\
\hline \multicolumn{3}{|l|}{ Shigella spp. } \\
\hline Stool culture & 97 & 81,100 \\
\hline Stool PCR & 90 & 74,97 \\
\hline Oral swab PCR & 33 & 18,53 \\
\hline \multicolumn{3}{|c|}{ Shiga toxin-producing Escherichia coli (STEC) } \\
\hline Stool culture & 87 & 68,96 \\
\hline Stool PCR & 80 & 61,92 \\
\hline Oral swab PCR & 33 & 18,53 \\
\hline \multicolumn{3}{|l|}{ Vibrio cholera } \\
\hline Stool culture & 93 & 76,99 \\
\hline Stool PCR & 83 & 65,94 \\
\hline Oral swab PCR & 33 & 18,53 \\
\hline \multicolumn{3}{|l|}{ Yersinia enterocolitica } \\
\hline Stool culture & 93 & 76,99 \\
\hline Stool PCR & 83 & 65,94 \\
\hline Oral swab PCR & 33 & 18,53 \\
\hline \multicolumn{3}{|l|}{ Viral pathogens } \\
\hline \multicolumn{3}{|c|}{ Adenovirus (any serotype) } \\
\hline Stool PCR & 51 & 34,68 \\
\hline Oral swab PCR & 31 & 17,49 \\
\hline \multicolumn{3}{|l|}{ Adenovirus 40/41 } \\
\hline Stool PCR & 81 & 63,91 \\
\hline Oral swab PCR & 54 & 37,71 \\
\hline \multicolumn{3}{|l|}{ Astrovirus } \\
\hline Stool PCR & 83 & 66,93 \\
\hline Oral swab PCR & 47 & 30,65 \\
\hline
\end{tabular}


TABle 1: Continued.

\begin{tabular}{|c|c|c|}
\hline Pathogen diagnostic test & $\begin{array}{c}\text { Proportion } \\
\text { agreement } \\
N(\%)\end{array}$ & $\begin{array}{c}95 \% \text { confidence } \\
\text { interval }\end{array}$ \\
\hline \multicolumn{3}{|l|}{ Norovirus GI/GII } \\
\hline Stool PCR & 94 & 80,99 \\
\hline Oral swab PCR & 60 & 42,76 \\
\hline \multicolumn{3}{|l|}{ Rotavirus } \\
\hline Stool PCR & 97 & 84,100 \\
\hline Oral swab PCR & 43 & 28,60 \\
\hline \multicolumn{3}{|l|}{ Sapovirus } \\
\hline Stool PCR & 75 & 57,87 \\
\hline Oral swab PCR & 40 & 24,58 \\
\hline \multicolumn{3}{|l|}{ Parasitic pathogens } \\
\hline \multicolumn{3}{|l|}{ Cryptosporidium spp. } \\
\hline Stool ova and parasite & 86 & 66,95 \\
\hline Stool PCR & 68 & 48,83 \\
\hline Stool EIA & 64 & 44,81 \\
\hline \multicolumn{3}{|l|}{ Entamoeba histolytica } \\
\hline Stool ova and parasite & 57 & 37,75 \\
\hline Stool culture & 68 & 48,83 \\
\hline Stool PCR & 61 & 41,78 \\
\hline Stool EIA & 75 & 55,89 \\
\hline \multicolumn{3}{|l|}{ Giardia lamblia } \\
\hline Stool ova and parasite & 86 & 66,95 \\
\hline Stool PCR & 68 & 48,83 \\
\hline Stool EIA & 75 & 55,89 \\
\hline
\end{tabular}

EIA, enzyme immunoassay; PCR, polymerase chain reaction. Stool culture, ova and parasite, and EIA: bulk stool and/or rectal swab.

3.2.2. Expert Panel: Meeting. Twelve of 14 (86\%) expert panel members convened at a meeting on March 5, 2016, in Edmonton, Alberta. The discussion focused on achieving definitions which could obtain broad endorsement by experts. The results of the advisory panel survey (Table 1) and the first expert panel survey (Table 2) were presented and used to modify the definitions. The definitions for all 19 pathogens were discussed and revised with the meeting focused primarily on reviewing the six agents with indeterminate ratings. Revisions included the specific wording of both the definition and the agent. For example, the generic term "nucleic acid test" (NAT) was adopted to replace more specific terminology such as PCR. Yersinia pseudotuberculosis was removed from the definition for Yersinia enterocolitica because the expert panel felt it is unclear if Yersinia pseudotuberculosis causes GI illness. For viruses, adenovirus (any serotype) was reworded to adenovirus (nontyped). For parasites, Entamoeba histolytica was updated to Entamoeba histolytica/dispar because, although dispar is not pathogenic, the two agents cannot be differentiated using direct microscopy or by most antigen-detection tests [25-27]. The definitions that emerged from this process were then recirculated via a final survey to all attendees.

3.2.3. Expert Panel: Postmeeting Survey. All twelve experts who attended the panel meeting completed the final survey which was distributed on March 21, 2016 (100\% response rate; Table 3). Eight of the final definitions had a proportional agreement of $100 \%$. C. difficile and E. histolytica/dispar did not achieve the a priori specified threshold of $\geq 67 \%$ agreement. Sixteen of the 19 (84\%) modified definitions had a higher proportion agreement than the definitions presented in the expert panel premeeting survey.

\section{Discussion}

This rigorous and systematic process provides expert consensus-based diagnostic test guidance definitions for 17 organisms contained in gastroenteritis nonculture detection panels. These definitions provide guidance to healthcare providers on the interpretation of positive diagnostic test results in the era of multianalyte molecular diagnostics. We identified two pathogens (C. difficile and E. histolytica/dispar) for which further research and definition development is required.

Our definition work is important as multianalyte enteric pathogen detection approaches are rapidly being adopted across North America. Many healthcare providers may have a limited understanding that these molecular techniques detect nucleic acids of targeted organisms but do not differentiate nonviable organisms or free DNA/RNA from viable pathogens. Positive results generated by molecular assays do not definitively distinguish between asymptomatic carriage, subclinical infection, active disease, resolved disease, or the presence of nucleic acids originating in nonpathogens. They also do not provide definitive information about virulence potential, and asymptomatic children have been found to have high rates of enteric pathogen identification $[17,28]$.

A positive $C$. difficile test represents the classic challenge clinicians face in multianalyte arrays as its presence may represent colonization and not pathogenic infection, particularly in infancy $[11,13,28,29]$. Many multianalyte panels also identify organisms that were not previously routinely sought, such as enteroaggregative E. coli (EAEC), and enteropathogenic E. coli (EPEC). The latter two bacteria have been identified in $84 \%$ of mixed infections, raising questions about the clinical significance of their identification and the validity of the definitions employed [13]. As such, the definitions developed in our study can serve as a starting point for clinicians interpreting the results of multianalyte arrays.

Our study also reflects current understanding of the use of oral swab NAT for the diagnosis of bacterial and viral enteric organisms. The paucity of evidence regarding the utility of oral swabs is reflected in the poor ratings for the use of oral swabs in our advisory panel survey and has subsequently been supported by a recent study [21]. As a result, oral swabs are not included in any of the definitions with the exception of norovirus for which there is some evidence of clinical utility $[23,30]$.

We were unable to develop consensus-based diagnostic test guidance definitions for two pathogens, $C$. difficile and $E$. histolytica/dispar. This is not surprising given the challenges surrounding the accurate diagnosis of $C$. difficile. Among healthy adults, asymptomatic $C$. difficile colonization prevalence varies between 0 [31] and 7\% [32], and it is even higher in healthy newborns and infants [33]. The prevalence of $C$. difficile colonization decreases from $35 \%$ to $40 \%$ during 
TABLE 2: Expert panel survey, prior to in-person meeting, where attendees rated the degree to which they agreed that if the provided definition was met, in a child with vomiting and/or diarrhea, the pathogen is highly likely to be causative of clinical illness.

\begin{tabular}{|c|c|c|c|c|c|c|c|}
\hline Pathogen & Definition & $\begin{array}{l}\text { Strongly } \\
\text { disagree }\end{array}$ & Disagree & $\begin{array}{l}\text { Neither } \\
\text { agree nor } \\
\text { disagree }\end{array}$ & Agree & $\begin{array}{l}\text { Strongly } \\
\text { agree }\end{array}$ & $\begin{array}{l}\text { Proportion } \\
\text { agreement } \\
\quad(\%)\end{array}$ \\
\hline \multicolumn{8}{|c|}{ Bacterial pathogens, $N(\%)$} \\
\hline Aeromonas & $\begin{array}{c}\text { Isolation of Aeromonas in a stool } \\
\text { specimen via culture or PCR }\end{array}$ & 0 & 0 & $2 / 14(14 \%)$ & $\begin{array}{c}9 / 14 \\
(64 \%)\end{array}$ & $\begin{array}{c}3 / 14 \\
(21 \%)\end{array}$ & 85 \\
\hline Campylobacter & $\begin{array}{l}\text { Isolation of Campylobacter spp. from } \\
\text { a stool specimen via culture or PCR }\end{array}$ & 0 & 0 & $4 / 14(29 \%)$ & $\begin{array}{c}6 / 14 \\
(43 \%)\end{array}$ & $\begin{array}{c}4 / 14 \\
(29 \%)\end{array}$ & 72 \\
\hline $\begin{array}{l}\text { Clostridium } \\
\text { difficile }\end{array}$ & $\begin{array}{l}\text { A positive toxin A or B assay for } \\
\text { Clostridium difficile from a stool } \\
\text { specimen via PCR for toxin A/B }\end{array}$ & $1 / 14(7 \%)$ & $\begin{array}{c}4 / 14 \\
(29 \%)\end{array}$ & 4/14 (29\%) & $\begin{array}{c}2 / 14 \\
(14 \%)\end{array}$ & $\begin{array}{l}(3 / 14) \\
(21 \%)\end{array}$ & 36 \\
\hline Edwardsiella & $\begin{array}{l}\text { Isolation of Edwardsiella in a stool } \\
\text { specimen via culture or PCR }\end{array}$ & $1 / 14(7 \%)$ & 0 & $7 / 14(50 \%)$ & $\begin{array}{c}6 / 14 \\
(43 \%)\end{array}$ & 0 & 43 \\
\hline $\begin{array}{l}\text { Escherichia coli } \\
\text { O157: H7 }\end{array}$ & $\begin{array}{c}\text { Isolation of Escherichia coli } \mathrm{O} 157: \mathrm{H} 7 \\
\text { from a stool specimen via culture, EIA, } \\
\text { or PCR }\end{array}$ & 0 & 0 & 0 & $\begin{array}{c}4 / 14 \\
(29 \%)\end{array}$ & $\begin{array}{l}10 / 14 \\
(71 \%)\end{array}$ & 100 \\
\hline $\begin{array}{l}\text { Escherichia coli } \\
\text { (non-O157: H7) }\end{array}$ & $\begin{array}{c}\text { Isolation of Shiga toxin-producing } \\
\text { Escherichia coli (non-O157:H7) from } \\
\text { a stool specimen via culture, EIA, or } \\
\text { PCR }\end{array}$ & 0 & 0 & $1 / 14(7 \%)$ & $\begin{array}{c}8 / 14 \\
(57 \%)\end{array}$ & $\begin{array}{c}5 / 14 \\
(36 \%)\end{array}$ & 93 \\
\hline Salmonella & $\begin{array}{c}\text { Isolation of spp. from a stool specimen } \\
\text { via culture or PCR }\end{array}$ & 0 & 0 & $4 / 13(31 \%)$ & $\begin{array}{c}6 / 13 \\
(46 \%)\end{array}$ & $\begin{array}{c}3 / 13 \\
(23 \%)\end{array}$ & 69 \\
\hline Shigella & $\begin{array}{l}\text { Isolation of Shigella spp. from a stool } \\
\text { specimen via culture or PCR }\end{array}$ & 0 & 0 & $1 / 13(8 \%)$ & $\begin{array}{c}8 / 13 \\
(62 \%)\end{array}$ & $\begin{array}{c}4 / 13 \\
(31 \%)\end{array}$ & 93 \\
\hline $\begin{array}{l}\text { Vibrio cholerae } \\
\text { serotype } \\
\text { O1 or O139 }\end{array}$ & $\begin{array}{c}\text { Isolation of cholera toxin-producing } \\
\text { Vibrio cholerae serotype O1 or O139 } \\
\text { from a stool specimen via culture or } \\
\text { PCR }\end{array}$ & 0 & 0 & 2/13 (15\%) & $\begin{array}{c}4 / 13 \\
(31 \%)\end{array}$ & $\begin{array}{c}7 / 13 \\
(54 \%)\end{array}$ & 85 \\
\hline $\begin{array}{l}\text { Yersinia } \\
\text { enterocolitica }\end{array}$ & $\begin{array}{c}\text { Isolation of Yersinia enterocolitica or } \\
\text { Yersinia pseudotuberculosis from a stool } \\
\text { specimen via culture or PCR }\end{array}$ & 0 & $\begin{array}{l}1 / 14 \\
(7 \%)\end{array}$ & $2 / 14(14 \%)$ & $\begin{array}{c}8 / 14 \\
(57 \%)\end{array}$ & $\begin{array}{c}3 / 14 \\
(21 \%)\end{array}$ & 79 \\
\hline \multicolumn{8}{|c|}{ Viral pathogens, $N(\%)$} \\
\hline Rotavirus & $\begin{array}{l}\text { Isolation of rotavirus from stool } \\
\text { specimen by EM, EIA, latex } \\
\text { agglutination, or PCR }\end{array}$ & 0 & 0 & 0 & $\begin{array}{c}8 / 14 \\
(57 \%)\end{array}$ & $\begin{array}{c}6 / 14 \\
(43 \%)\end{array}$ & 100 \\
\hline $\begin{array}{l}\text { Adenovirus } \\
\text { (any serotype) }\end{array}$ & $\begin{array}{c}\text { Isolation of adenovirus in a stool } \\
\text { specimen via PCR }\end{array}$ & 0 & $\begin{array}{c}2 / 14 \\
(14 \%)\end{array}$ & $7 / 14(50 \%)$ & $\begin{array}{c}5 / 14 \\
(36 \%)\end{array}$ & 0 & 36 \\
\hline Adenovirus $40 / 41$ & $\begin{array}{c}\text { Isolation of adenovirus } 40 / 41 \text { in a stool } \\
\text { specimen via PCR }\end{array}$ & 0 & 0 & $2 / 14(14 \%)$ & $\begin{array}{l}11 / 14 \\
(79 \%)\end{array}$ & $\begin{array}{l}1 / 14 \\
(7 \%)\end{array}$ & 86 \\
\hline Norovirus & $\begin{array}{l}\text { Isolation of norovirus from a stool } \\
\text { specimen or ORAL SWAB via PCR }\end{array}$ & 0 & 0 & 0 & $\begin{array}{l}(8 / 14) \\
(57 \%)\end{array}$ & $\begin{array}{c}6 / 14 \\
(43 \%)\end{array}$ & 100 \\
\hline Sapovirus & $\begin{array}{l}\text { Isolation of sapovirus in a stool } \\
\text { specimen via PCR }\end{array}$ & 0 & 0 & 2/14 (14\%) & $\begin{array}{c}9 / 14 \\
(64 \%) \\
\end{array}$ & $\begin{array}{c}3 / 14 \\
(21 \%) \\
\end{array}$ & 85 \\
\hline \multicolumn{8}{|c|}{ Parasitic pathogens, $N(\%)$} \\
\hline Cryptosporidium & $\begin{array}{c}\text { Isolation of Cryptosporidium from } \\
\text { a stool specimen via microscopy, EIA, } \\
\text { or PCR }\end{array}$ & 0 & $\begin{array}{l}1 / 14 \\
(7 \%)\end{array}$ & $2 / 14(14 \%)$ & $\begin{array}{c}7 / 14 \\
(50 \%)\end{array}$ & $\begin{array}{c}4 / 14 \\
(29 \%)\end{array}$ & 79 \\
\hline $\begin{array}{l}\text { Entamoeba } \\
\text { histolytica }\end{array}$ & $\begin{array}{l}\text { Detection of Entamoeba histolytica } \\
\text { from a stool specimen via microscopy }\end{array}$ & $1 / 14(7 \%)$ & $\begin{array}{l}1 / 14 \\
(7 \%)\end{array}$ & $4 / 14(29 \%)$ & $\begin{array}{c}4 / 14 \\
(29 \%)\end{array}$ & $\begin{array}{c}4 / 14 \\
(29 \%)\end{array}$ & 58 \\
\hline Giardia lamblia & $\begin{array}{l}\text { Detection of Giardia lamblia in a stool } \\
\text { specimen via microscopy or EIA }\end{array}$ & 0 & $\begin{array}{l}1 / 14 \\
(7 \%)\end{array}$ & $1 / 14(7 \%)$ & $\begin{array}{l}10 / 14 \\
(71 \%)\end{array}$ & $\begin{array}{c}2 / 14 \\
(14 \%)\end{array}$ & 85 \\
\hline
\end{tabular}

EIA, enzyme immunoassay; PCR, polymerase chain reaction. Stool specimen includes bulk stool and/or rectal swab. All definitions are in the context of a single-positive pathogen.

the first month of life to approximately $15 \%$ by one year of age [34]. However, $10-20 \%$ of older infants continue to asymptomatically carry toxigenic organisms and the associated toxin genes, and in many asymptomatic children, the toxins are well expressed $[28,35]$. In addition, there is limited evidence on the duration of the colonized state, the risk factors related to transmission, and the mechanisms underlying progression from colonization to disease [33]. The lack of a standardized definition for asymptomatic colonization, or carriage, makes the interpretation of test findings, and the development of a diagnostic test guidance definition, difficult. Further research is required to develop 
TABle 3: Definitions that emerged from in-person meeting and subsequently circulated for final evaluation by the definition meeting attendees.

\begin{tabular}{|c|c|c|c|c|c|c|c|c|}
\hline Pathogen & Case definition & $\begin{array}{l}\text { Strongly } \\
\text { disagree }\end{array}$ & Disagree & $\begin{array}{l}\text { Neither } \\
\text { agree nor } \\
\text { disagree }\end{array}$ & Agree & $\begin{array}{l}\text { Strongly } \\
\text { agree }\end{array}$ & $\begin{array}{l}\text { Proportion } \\
\text { agreement } \\
(\%)\end{array}$ & $\begin{array}{l}\text { Dropped diagnostics } \\
\text { from initial (1) and } \\
\text { second survey (2) }\end{array}$ \\
\hline \multicolumn{9}{|c|}{ Bacterial pathogens, $N(\%)$} \\
\hline Aeromonas & $\begin{array}{c}\text { Detection of Aeromonas in } \\
\text { a stool specimen via culture or } \\
\text { NAT (e.g., PCR) }\end{array}$ & 0 & 0 & $\begin{array}{c}3 / 12 \\
(25 \%)\end{array}$ & $\begin{array}{c}8 / 12 \\
(67 \%)\end{array}$ & $\begin{array}{l}1 / 12 \\
(8 \%)\end{array}$ & 75 & $\begin{array}{c}\text { Oral swab PCR (1); } \\
\text { none (2) }\end{array}$ \\
\hline Campylobacter & $\begin{array}{l}\text { Detection of Campylobacter } \\
\text { spp. from a stool specimen via } \\
\text { culture or NAT (e.g., PCR) } \\
\text { Detection of Clostridium }\end{array}$ & 0 & 0 & 0 & $\begin{array}{c}8 / 12 \\
(67 \%)\end{array}$ & $\begin{array}{c}4 / 12 \\
(33 \%)\end{array}$ & 100 & $\begin{array}{c}\text { Oral swab PCR (1); } \\
\text { none (2) }\end{array}$ \\
\hline $\begin{array}{l}\text { Clostridium } \\
\text { difficile }\end{array}$ & $\begin{array}{l}\text { difficile toxin A or B from } \\
\text { a stool specimen via NAT (e. } \\
\text { g., PCR) for toxin A/B }\end{array}$ & 0 & $\begin{array}{c}2 / 12 \\
(17 \%)\end{array}$ & $\begin{array}{c}5 / 12 \\
(42 \%)\end{array}$ & $\begin{array}{c}5 / 12 \\
(42 \%)\end{array}$ & 0 & 42 & $\begin{array}{l}\text { Stool EIA, oral swab } \\
\text { PCR (1); none (2) }\end{array}$ \\
\hline Edwardsiella & $\begin{array}{l}\text { Detection of Edwardsiella in } \\
\text { a stool specimen via culture }\end{array}$ & 0 & 0 & $\begin{array}{c}3 / 12 \\
(25 \%)\end{array}$ & $\begin{array}{c}8 / 12 \\
(67 \%)\end{array}$ & $\begin{array}{l}1 / 12 \\
(8 \%)\end{array}$ & 75 & $\begin{array}{l}\text { Stool PCR, oral swab } \\
\text { PCR (1); none (2) }\end{array}$ \\
\hline $\begin{array}{l}\text { Escherichia } \\
\text { coli } \\
\text { O157: H7 }\end{array}$ & $\begin{array}{c}\text { Detection of Escherichia coli } \\
\text { O157: H7 from a stool } \\
\text { specimen via culture, EIA or } \\
\text { NAT (e.g., PCR) }\end{array}$ & 0 & 0 & 0 & $\begin{array}{c}5 / 12 \\
(42 \%)\end{array}$ & $\begin{array}{c}7 / 12 \\
(58 \%)\end{array}$ & 100 & $\begin{array}{c}\text { Oral swab PCR (1); } \\
\text { none (2) }\end{array}$ \\
\hline $\begin{array}{l}\text { Escherichia } \\
\text { coli } \\
\text { (non-O157: } \\
\text { H7) }\end{array}$ & $\begin{array}{l}\text { Detection of shiga toxin- } \\
\text { producing Escherichia coli } \\
\text { (non-O157: H7) from a stool } \\
\text { specimen via culture, EIA or } \\
\text { NAT (e.g., PCR) }\end{array}$ & 0 & 0 & 0 & $\begin{array}{c}7 / 12 \\
(58 \%)\end{array}$ & $\begin{array}{c}5 / 12 \\
(42 \%)\end{array}$ & 100 & $\begin{array}{c}\text { Oral swab PCR (1); } \\
\text { none (2) }\end{array}$ \\
\hline Salmonella & $\begin{array}{l}\text { Detection of Salmonella spp. } \\
\text { from a stool specimen via } \\
\text { culture or NAT (e.g., PCR) }\end{array}$ & 0 & 0 & 0 & $\begin{array}{c}7 / 12 \\
(58 \%)\end{array}$ & $\begin{array}{c}5 / 12 \\
(42 \%)\end{array}$ & 100 & $\begin{array}{c}\text { Oral swab PCR (1); } \\
\text { none (2) }\end{array}$ \\
\hline Shigella & $\begin{array}{l}\text { Detection of Shigella spp. from } \\
\text { a stool specimen via culture or } \\
\text { NAT (e.g., PCR) }\end{array}$ & 0 & 0 & 0 & $\begin{array}{c}6 / 12 \\
(50 \%)\end{array}$ & $\begin{array}{c}6 / 12 \\
(50 \%)\end{array}$ & 100 & $\begin{array}{c}\text { Oral swab PCR (1); } \\
\text { none (2) }\end{array}$ \\
\hline $\begin{array}{l}\text { Vibrio } \\
\text { cholerae } \\
\text { serotype } \\
\text { O1 or O139 }\end{array}$ & $\begin{array}{c}\text { Detection of Vibrio cholerae } \\
\text { serotype O1 or O139 from } \\
\text { a stool specimen via culture or } \\
\text { NAT (e.g., PCR) }\end{array}$ & 0 & 0 & $1 / 12(8 \%)$ & $\begin{array}{c}5 / 12 \\
(42 \%)\end{array}$ & $\begin{array}{c}6 / 12 \\
(50 \%)\end{array}$ & 92 & $\begin{array}{c}\text { Oral swab PCR (1); } \\
\text { none (2) }\end{array}$ \\
\hline $\begin{array}{l}\text { Yersinia } \\
\text { enterocolitica }\end{array}$ & $\begin{array}{c}\text { Detection of Yersinia } \\
\text { enterocolitica from a stool } \\
\text { specimen via culture or NAT } \\
\text { (e.g., PCR) }\end{array}$ & 0 & 0 & 0 & $\begin{array}{c}6 / 12 \\
(50 \%)\end{array}$ & $\begin{array}{c}6 / 12 \\
(50 \%)\end{array}$ & 100 & $\begin{array}{c}\text { Oral swab PCR (1); } \\
\text { none (2) }\end{array}$ \\
\hline \multicolumn{9}{|c|}{ Viral pathogens, $N(\%)$} \\
\hline $\begin{array}{l}\text { Adenovirus } \\
\text { (nontyped) }\end{array}$ & $\begin{array}{c}\text { Detection of adenovirus } \\
\text { (nontyped) in a stool } \\
\text { specimen by EM, EIA, or NAT } \\
\text { (e.g., PCR) }\end{array}$ & $\begin{array}{l}1 / 12 \\
(8 \%)\end{array}$ & $\begin{array}{l}1 / 12 \\
(8 \%)\end{array}$ & $1 / 12(8 \%)$ & $\begin{array}{c}8 / 12 \\
(67 \%)\end{array}$ & $\begin{array}{l}1 / 12 \\
(8 \%)\end{array}$ & 75 & $\begin{array}{c}\text { Oral swab PCR (1); } \\
\text { none (2) }\end{array}$ \\
\hline $\begin{array}{l}\text { Adenovirus } \\
40 / 41\end{array}$ & $\begin{array}{l}\text { Detection of adenovirus } 40 / 41 \\
\text { in a stool specimen via EIA or } \\
\text { NAT (e.g., PCR) }\end{array}$ & 0 & 0 & $1 / 12(8 \%)$ & $\begin{array}{c}6 / 12 \\
(50 \%)\end{array}$ & $\begin{array}{c}5 / 12 \\
(42 \%)\end{array}$ & 92 & $\begin{array}{c}\text { Oral swab PCR (1); } \\
\text { none (2) }\end{array}$ \\
\hline Astrovirus & $\begin{array}{c}\text { Detection of astrovirus in } \\
\text { a stool specimen via NAT (e. } \\
\text { g., PCR) }\end{array}$ & 0 & $\begin{array}{l}1 / 12 \\
(8 \%)\end{array}$ & $1 / 12(8 \%)$ & $\begin{array}{c}8 / 12 \\
(67 \%)\end{array}$ & $\begin{array}{c}2 / 12 \\
(17 \%)\end{array}$ & 84 & $\begin{array}{c}\text { Oral swab PCR (1); } \\
\text { none (2) }\end{array}$ \\
\hline Norovirus & $\begin{array}{l}\text { Detection of norovirus from } \\
\text { a stool specimen or ORAL } \\
\text { SWAB via NAT (e.g., PCR) }\end{array}$ & 0 & 0 & 0 & $\begin{array}{c}8 / 12 \\
(67 \%)\end{array}$ & $\begin{array}{c}4 / 12 \\
(33 \%)\end{array}$ & 100 & None (1 and 2 ) \\
\hline Rotavirus & $\begin{array}{l}\text { Detection of rotavirus from } \\
\text { a stool specimen by EM, EIA } \\
\text { or NAT (e.g., PCR) }\end{array}$ & 0 & 0 & 0 & $\begin{array}{c}4 / 12 \\
(33 \%)\end{array}$ & $\begin{array}{c}8 / 12 \\
(67 \%)\end{array}$ & 100 & $\begin{array}{l}\text { Oral swab PCR (1); } \\
\text { latex agglutination } \\
(2)\end{array}$ \\
\hline Sapovirus & $\begin{array}{c}\text { Detection of sapovirus in } \\
\text { a stool specimen via NAT (e. } \\
\text { g., PCR) }\end{array}$ & 0 & 0 & $1 / 12(8 \%)$ & $\begin{array}{c}8 / 12 \\
(67 \%)\end{array}$ & $\begin{array}{c}3 / 12 \\
(25 \%)\end{array}$ & 92 & $\begin{array}{c}\text { Oral swab PCR (1); } \\
\text { none (2) }\end{array}$ \\
\hline
\end{tabular}


TABLE 3: Continued.

\begin{tabular}{|c|c|c|c|c|c|c|c|c|}
\hline Pathogen & Case definition & $\begin{array}{l}\text { Strongly } \\
\text { disagree }\end{array}$ & Disagree & $\begin{array}{l}\text { Neither } \\
\text { agree nor } \\
\text { disagree }\end{array}$ & Agree & $\begin{array}{c}\text { Strongly } \\
\text { agree }\end{array}$ & $\begin{array}{l}\text { Proportion } \\
\text { agreement } \\
(\%)\end{array}$ & $\begin{array}{l}\text { Dropped diagnostics } \\
\text { from initial (1) and } \\
\text { second survey (2) }\end{array}$ \\
\hline \multicolumn{9}{|c|}{ Parasitic pathogens, $N(\%)$} \\
\hline Cryptosporidium & $\begin{array}{l}\text { Detection of Cryptosporidium } \\
\text { from a stool specimen via } \\
\text { microscopy, EIA or NAT (e.g., } \\
\text { PCR) }\end{array}$ & 0 & 0 & $1 / 12(8 \%)$ & $\begin{array}{c}6 / 12 \\
(50 \%)\end{array}$ & $\begin{array}{c}5 / 12 \\
(42 \%)\end{array}$ & 92 & $\begin{array}{l}\text { Stool ova and } \\
\text { parasite, oral swab } \\
\text { PCR (1); none (2) }\end{array}$ \\
\hline $\begin{array}{l}\text { Entamoeba } \\
\text { histolytica/dispar }\end{array}$ & $\begin{array}{l}\text { Detection of Entamoeba } \\
\text { histolytica/dispar from a stool } \\
\text { specimen via microscopy }\end{array}$ & 0 & $\begin{array}{l}1 / 12 \\
(8 \%)\end{array}$ & $\begin{array}{c}7 / 12 \\
(58 \%)\end{array}$ & $\begin{array}{c}4 / 12 \\
(33 \%)\end{array}$ & 0 & 33 & $\begin{array}{l}\text { Stool ova and } \\
\text { parasite, stool } \\
\text { culture, PCR, and } \\
\text { EIA (1); none (2) }\end{array}$ \\
\hline $\begin{array}{l}\text { Giardia } \\
\text { lamblia }\end{array}$ & $\begin{array}{c}\text { Detection of Giardia lamblia } \\
\text { in a stool specimen via } \\
\text { microscopy or EIA }\end{array}$ & 0 & 0 & $1 / 12(8 \%)$ & $\begin{array}{c}8 / 12 \\
(67 \%)\end{array}$ & $\begin{array}{c}3 / 12 \\
(25 \%)\end{array}$ & 92 & $\begin{array}{l}\text { Stool ova and } \\
\text { parasite, } \\
\text { PCR (1); none (2) }\end{array}$ \\
\hline
\end{tabular}

EIA, enzyme immunoassay; EM, electron microscopy; NAT, nucleic acid test, PCR, polymerase chain reaction. Stool specimen includes bulk stool and/or rectal swab. All definitions are in the context of a single-positive pathogen.

an evidence based, standardized definition for C. difficile disease, and equally importantly, colonization.

In the developing world, E. histolytica is a common cause of protozoan morbidity and mortality [36]. However, infection is uncommon in North America, and occurs primarily in immigrants and travelers from developing countries [37]. Nonetheless, asymptomatic colonization is common, occurring in up to $4 \%$ of individuals in high-risk areas [38], such as California, and it occurs with both $E$. histolytica and the nonpathogenic E. dispar. Colonization with the morphologically identical parasite $E$. dispar is three times more common in developing countries and at least ten times more common in developed nations [37]. Routine diagnostic tests such as direct microscopy cannot differentiate between E. histolytica and E. dispar based on morphologic criteria, so most laboratory reports indicate $E$. histolytica/dispar [14]. The relatively low prevalence in North America, combined with the high colonization rates with both the pathogenic, and nonpathogenic form, and the difficulty in differentiating the two, likely account for the lack of consensus for a diagnostic test guidance definition. It should also be noted that the panel consisted of individuals who have largely practiced in North America, where amebiasis is exceptionally rare in childhood. However, recently published work on the most common causes of diarrhea using molecular methods indicated that even in Asia and Africa, the most common causes of diarrhea were Shigella, rotavirus, adenovirus 40/41, heat-stable enterotoxinproducing E. coli, Cryptosporidium, and Campylobacter, which supports the broad-based utility of our clinical definitions [2].

A strength of this project is the use of a rigorous consensus methodology consisting of multiple survey rounds and a face-to-face meeting, which enabled dialogue [20]. Similar methods have been used to combine best evidence and expert opinion in a number of clinical and research settings [39, 40] including antimicrobial stewardship [41]. Both our advisory and expert panels had geographic representation from throughout North America and including a diversity of disciplines, thereby contributing to the utility, credibility, and generalizability of our definitions. We had representation from a broad spectrum of stakeholders involved in the diagnosis and management of pediatric infectious enteric diseases including front-line clinicians, medical microbiologists, infectious disease specialists, and public health experts. The engagement of our expert panel, with $86 \%$ of our expert panel participating in the face-to-face meeting, and a $100 \%$ response rate on our final survey, is evidence of the relevance and importance of the topic and the validity of the results. Nonetheless, our definitions can be considered as a derivation set; future work should include a validation with a distinct expert panel.

It should be noted that the definitions provided are only applicable in the setting of a test that is positive for a single pathogen. Clinicians should also be cognizant that in most cases where the definitions provided are met, therapy remains predominantly supportive and few of the enteropathogens included in Table 3 require antimicrobial treatment, which can at times even be detrimental [42]. Although multiple pathogens are detected in $~ 15 \%$ of stool specimens in children with diarrhea [10], determining guidelines for the interpretation of a positive test for more than one pathogen was beyond the scope of this project. The guidance provided is also very general and does not incorporate the myriad of clinical scenarios that can occur. The definitions are not intended to replace expert opinion (e.g., infectious disease specialist, medical microbiologist) but rather are intended to assist clinicians in the context of otherwise healthy children with typical clinical features and $<7$ days of symptoms. We also identified two agents, $C$. difficile and E. histolytica/dispar, for which further research is required to develop accurate diagnostic test guidance definitions. Prospective research currently underway [7] is attempting to validate these definitions in the clinical setting of pediatric enteric illness.

We also did not assess the confidence in the individual items included in each definition, nor the potential role of quantitative molecular techniques [2]. Thus, although the definitions may include multiple diagnostic testing methods, the test characteristics of each modality vary. While these 
definitions may lead clinicians to conclude that all diagnostic tests are created equal, as diagnostic testing evolves and progresses, less accurate tests are phased out and replaced by superior diagnostic tests. It should also be noted that our process did not include some of the diarrheagenic E. coli strains (e.g., ETEC, EAEC, and EPEC) that are included in some multianalyte tests while it did include some pathogens not routinely identified by all laboratories (e.g., Edwardsiella). This likely stems from the fact that few clinicians and microbiologists have any significant experience with the detection of these enteric pathogens outside of research settings. Currently, very few commercially available assays include all these pathogen targets [43]. As experience is accumulated with the detection of these pathogens in clinical laboratories, it would certainly be useful to include them in a subsequent evaluation. Finally, as we had to limit the number of study participants, and their expert opinions may not reflect the entire spectrum of expertise, our findings should not be interpreted as the only perspective on this topic.

In conclusion, we report a rigorous, systematic, expert consensus process that includes diagnostic test guidance definitions for 17 enteric organisms. These definitions can be employed by healthcare providers to interpret positive diagnostic test results in the era of multianalyte molecular diagnostics as we await further clinical data, particularly with respect to consideration of clinical settings and interpretation of detection of more than one pathogen. We also identified pathogens for which further definition development is required.

\section{Abbreviations}

EAEC: Enteroaggregative E. coli

EIA: Enzyme immunoassay

EPEC: Enteropathogenic E. coli

NAT: Nucleic acid test

PCR: Polymerase chain reaction

STEC: Shiga toxin-producing Escherichia coli.

\section{Data Availability}

All data generated or analysed during this study are included in this published article and the supplemental material.

\section{Ethical Approval}

Ethics approval for this study was obtained from the Conjoint Health Research Ethics Board of the University of Calgary.

\section{Conflicts of Interest}

The authors declare that they have no conflicts of interest.

\section{Acknowledgments}

This paper is on behalf of the Alberta Provincial Pediatric EnTeric Infection TEam (APPETITE). This research was funded in part by The Alberta Provincial Pediatric EnTeric Infection TEam (APPETITE), which was supported by an
Alberta Innovates-Health Solutions Collaborative Research Innovation Opportunity (CRIO) Team Grant. The Alberta Provincial Pediatric EnTeric Infection TEam (APPETITE) received in-kind support from Luminex Corporation and COPAN. All involved researchers would like to thank the APPETITE for its support. Additional support for APPETITE was provided by the Alberta Children's Hospital Research Institute (Calgary, Alberta) and the Women and Children's Health Research Institute (Edmonton, Alberta). Dr. Stephen Freedman was supported by the Alberta Children's Hospital Foundation Professorship in Child Health and Wellness.

\section{Supplementary Materials}

Supplemental Table 1: demographic information for participants of the initial survey. Supplemental Table 2: expert panel members. (Supplementary Materials)

\section{References}

[1] L. Liu, H. L. Johnson, S. Cousens et al., "Global, regional, and national causes of child mortality: an updated systematic analysis for 2010 with time trends since 2000," Lancet, vol. 379, no. 9832, pp. 2151-2161, 2012.

[2] J. Liu, J. A. Platts-Mills, and J. Juma, "Use of quantitative molecular diagnostic methods to identify causes of diarrhoea in children: a reanalysis of the GEMS case-control study," Lancet, vol. 388, no. 10051, pp. 1291-1301, 2016.

[3] WHO, World Health Statistics, World Health Organization, Geneva, Switzerland, 2011.

[4] M. D. Kirk, S. M. Pires, R. E. Black et al., "World health organization estimates of the global and regional disease burden of 22 foodborne bacterial, protozoal, and viral diseases, 2010: a data synthesis," PLoS Med, vol. 12, no. 12, article e1001921, 2015.

[5] M. K. Thomas, R. Murray, L. Flockhart et al., "Estimates of foodborne illness-related hospitalizations and deaths in Canada for 30 specified pathogens and unspecified agents," Foodborne Pathogens and Disease, vol. 12, no. 10, pp. 820-827, 2015.

[6] E. Scallan, P. M. Griffin, F. J. Angulo, R. V. Tauxe, and R. M. Hoekstra, "Foodborne illness acquired in the United States-unspecified agents," Emerging Infectious Diseases, vol. 17, no. 1, pp. 16-22, 2011.

[7] S. B. Freedman, B. E. Lee, M. Louie et al., "Alberta Provincial Pediatric EnTeric Infection TEam (APPETITE): epidemiology, emerging organisms, and economics," BMC Pediatrics, vol. 15, no. 1, p. 89, 2015.

[8] M. El-Shabrawi, M. Salem, M. Abou-Zekri et al., "The burden of different pathogens in acute diarrhoeal episodes among a cohort of Egyptian children less than five years old," Gastroenterology Review, vol. 3, pp. 173-180, 2015.

[9] D. M. Goldfarb, A. P. Steenhoff, J. M. Pernica et al., "Evaluation of anatomically designed flocked rectal swabs for molecular detection of enteric pathogens in children admitted to hospital with severe gastroenteritis in Botswana," Journal of Clinical Microbiology, vol. 52, no. 11, pp. 3922-3927, 2014.

[10] C. Stockmann, A. T. Pavia, B. Graham et al., "Detection of 23 gastrointestinal pathogens among children who present with diarrhea," Journal of the Pediatric Infectious Diseases Society, vol. 6, no. 3, pp. 231-238, 2016. 
[11] S. N. Buss, A. Leber, K. Chapin et al., "Multicenter evaluation of the BioFire FilmArray gastrointestinal panel for etiologic diagnosis of infectious gastroenteritis," Journal of Clinical Microbiology, vol. 53, no. 3, pp. 915-925, 2015.

[12] R. S. Huang, C. L. Johnson, L. Pritchard, R. Hepler, T. T. Ton, and J. J. Dunn, "Performance of the Verigene(R) enteric pathogens test, Biofire FilmArray gastrointestinal panel and Luminex xTAG(R) gastrointestinal pathogen panel for detection of common enteric pathogens," Diagnostic Microbiology and Infectious Disease, vol. 86, no. 4, pp. 336-339, 2016.

[13] A. Spina, K. G. Kerr, M. Cormican et al., "Spectrum of enteropathogens detected by the FilmArray GI Panel in a multicentre study of community-acquired gastroenteritis," Clinical Microbiology and Infection, vol. 21, no. 8, pp. 719-728, 2015.

[14] E. J. Baron, J. M. Miller, M. P. Weinstein et al., "A guide to utilization of the microbiology laboratory for diagnosis of infectious diseases: 2013 recommendations by the Infectious Diseases Society of America (IDSA) and the American Society for Microbiology (ASM)(a)," Clinical Infectious Diseases, vol. 57, no. 4, pp. e22-e121, 2013.

[15] R. L. Guerrant, T. Van Gilder, T. S. Steiner et al., "Practice guidelines for the management of infectious diarrhea," Clinical Infectious Diseases, vol. 32, no. 3, pp. 331-351, 2001.

[16] M. S. Riddle, H. L. DuPont, and A. C. Bradley, "ACG clinical guideline: diagnosis, treatment, and prevention of acute diarrheal infections in adults," The American Journal of Gastroenterology, vol. 111, pp. 602-622, 2016.

[17] R. Enserink, R. Scholts, P. Bruijning-Verhagen et al., "High detection rates of enteropathogens in asymptomatic children attending day care," PLoS One, vol. 9, no. 2, Article ID e89496, 2014.

[18] A. Guarino, S. Ashkenazi, D. Gendrel, A. Lo Vecchio, R. Shamir, and H. Szajewska, "European Society for Pediatric Gastroenterology, Hepatology, and Nutrition/ European Society for Pediatric Infectious Diseases evidence-based guidelines for the management of acute gastroenteritis in children in Europe: update 2014," Journal of Pediatric Gastroenterology and Nutrition, vol. 59, no. 1, pp. 132-152, 2014.

[19] C. Harris, F. Wilkinson, D. Mazza, and T. Turner, "Health for Kids Guideline Development G: evidence based guideline for the management of diarrhoea with or without vomiting in children," Australian Family Physician, vol. 37, no. 6, pp. 22-29, 2008.

[20] J. Jones and D. Hunter, "Consensus methods for medical and health services research,” BMJ, vol. 311, no. 7001, pp. 376-380, 1995.

[21] R. Zhuo, B. D. Parsons, B. E. Lee et al., "Identification of enteric viruses in oral swabs from children with acute gastroenteritis," The Journal of Molecular Diagnostics, vol. 20, no. 1, pp. 56-62, 2018.

[22] P. A. Harris, R. Taylor, R. Thielke, J. Payne, N. Gonzalez, and J. G. Conde, "Research electronic data capture (REDCap)a metadata-driven methodology and workflow process for providing translational research informatics support," Journal of Biomedical Informatics, vol. 42, no. 2, pp. 377-381, 2009.

[23] A. Kirby, W. Dove, L. Ashton, M. Hopkins, and N. A. Cunliffe, "Detection of norovirus in mouthwash samples from patients with acute gastroenteritis," Journal of Clinical Virology, vol. 48, no. 4, pp. 285-287, 2010.
[24] V. Guru, G. M. Anderson, S. E. Fremes, G. T. O'Connor, F. L. Grover, and J. V. Tu, "Canadian CSQICP: the identification and development of Canadian coronary artery bypass graft surgery quality indicators," The Journal of Thoracic and Cardiovascular Surgery, vol. 130, no. 5, p. 1257, 2005.

[25] R. Haque, L. M. Neville, P. Hahn, and W. A. Petri Jr., "Rapid diagnosis of Entamoeba infection by using Entamoeba and Entamoeba histolytica stool antigen detection kits," Journal of Clinical Microbiology, vol. 33, no. 10, pp. 2558-2561, 1995.

[26] D. R. Pillai and K. C. Kain, "Immunochromatographic stripbased detection of Entamoeba histolytica-E. dispar and Giardia lamblia coproantigen," Journal of Clinical Microbiology, vol. 37, no. 9, pp. 3017-3019, 1999.

[27] L. S. Garcia, R. Y. Shimizu, and C. N. Bernard, "Detection of Giardia lamblia, Entamoeba histolytica/Entamoeba dispar, and Cryptosporidium parvum antigens in human fecal specimens using the triage parasite panel enzyme immunoassay," Journal of Clinical Microbiology, vol. 38, no. 9, pp. 3337-3340, 2000.

[28] D. M. Denno, N. Shaikh, J. R. Stapp et al., "Diarrhea etiology in a pediatric emergency department: a case control study," Clinical Infectious Diseases, vol. 55, no. 7, pp. 897-904, 2012.

[29] R. Khare, M. J. Espy, E. Cebelinski et al., "Comparative evaluation of two commercial multiplex panels for detection of gastrointestinal pathogens by use of clinical stool specimens," Journal of Clinical Microbiology, vol. 52, no. 10, pp. 3667-3673, 2014.

[30] A. Kirby, L. Ashton, and I. J. Hart, "Detection of norovirus infection in the hospital setting using vomit samples," Journal of Clinical Virology, vol. 51, no. 1, pp. 86-87, 2011.

[31] M. Hell, K. Sickau, G. Chmelizek et al., "Absence of Clostridium difficile in asymptomatic hospital staff," American Journal of Infection Control, vol. 40, no. 10, pp. 1023-1024, 2012.

[32] A. L. Galdys, J. S. Nelson, K. A. Shutt et al., "Prevalence and duration of asymptomatic Clostridium difficile carriage among healthy subjects in Pittsburgh, Pennsylvania," Journal of Clinical Microbiology, vol. 52, no. 7, pp. 24062409, 2014.

[33] L. Furuya-Kanamori, J. Marquess, L. Yakob et al., "Asymptomatic Clostridium difficile colonization: epidemiology and clinical implications," BMC Infectious Diseases, vol. 15, no. 1, p. 516, 2015.

[34] S. Jangi and J. T. Lamont, "Asymptomatic colonization by Clostridium difficile in infants: implications for disease in later life," Journal of Pediatric Gastroenterology and Nutrition, vol. 51, no. 1, pp. 2-7, 2010.

[35] J. Leibowitz, V. L. Soma, L. Rosen, C. C. Ginocchio, and L. G. Rubin, "Similar proportions of stool specimens from hospitalized children with and without diarrhea test positive for Clostridium difficile," The Pediatric Infectious Disease Journal, vol. 34, no. 3, pp. 261-266, 2015.

[36] S. L. Stanley Jr., “Amoebiasis," Lancet, vol. 361, no. 9362, pp. 1025-1034, 2003.

[37] W. A. Petri Jr. and U. Singh, "Diagnosis and management of amebiasis," Clinical Infectious Diseases, vol. 29, no. 5, pp. 1117-1125, 1999.

[38] California MSR, Selected Reportable Diseases: Report Weeks 49-52 (Dec 2-Dec 29, 2007), Division of Communicable Disease Control Surveillance and Statistics Section, California Department of Public Health, Sacramento, CA, USA, 2007.

[39] A. C. Plint, A. S. Stang, and L. A. Calder, "Establishing research priorities for patient safety in emergency medicine: 
a multidisciplinary consensus panel," International Journal of Emergency Medicine, vol. 8, p. 1, 2015.

[40] A. S. Stang, S. E. Straus, J. Crotts, D. W. Johnson, and A. Guttmann, "Quality indicators for high acuity pediatric conditions," Pediatrics, vol. 132, no. 4, pp. 752-762, 2013.

[41] C. M. van den Bosch, S. E. Geerlings, S. Natsch, J. M. Prins, and M. E. Hulscher, "Quality indicators to measure appropriate antibiotic use in hospitalized adults," Clinical Infectious Diseases, vol. 60, no. 2, pp. 281-291, 2015.

[42] S. B. Freedman, J. Xie, M. S. Neufeld, W. L. Hamilton, L. Hartling, and P. I. Tarr, "Shiga toxin-producing Escherichia coli infection, antibiotics, and risk of developing hemolytic uremic syndrome: a meta-analysis," Clinical Infectious Diseases, vol. 62, no. 10, pp. 1251-1258, 2016.

[43] M. Smieja and D. M. Goldfarb, "Molecular detection of diarrheal pathogens," Clinical Microbiology Newsletter, vol. 38, no. 17 , pp. $137-145,2016$. 


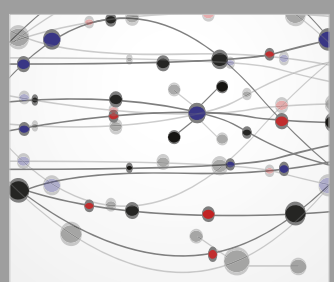

The Scientific World Journal
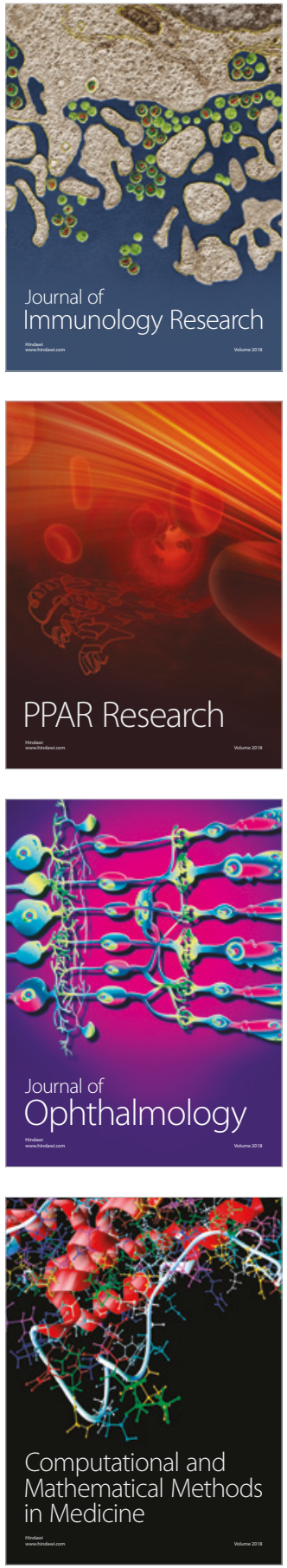

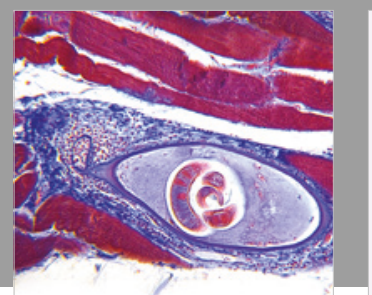

Gastroenterology Research and Practice

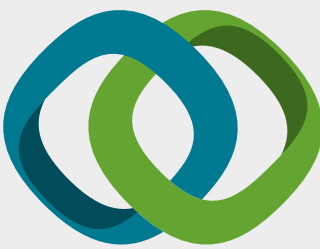

\section{Hindawi}

Submit your manuscripts at

www.hindawi.com
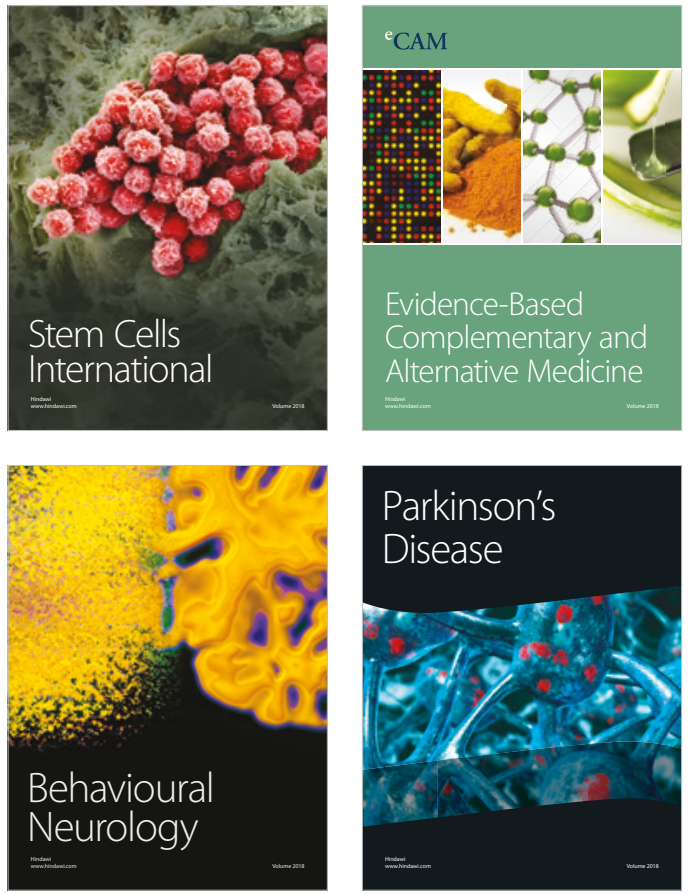

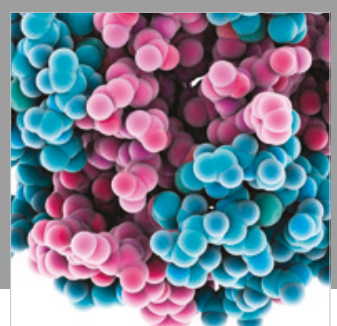

ournal of

Diabetes Research

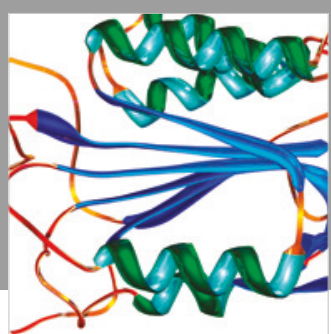

Disease Markers
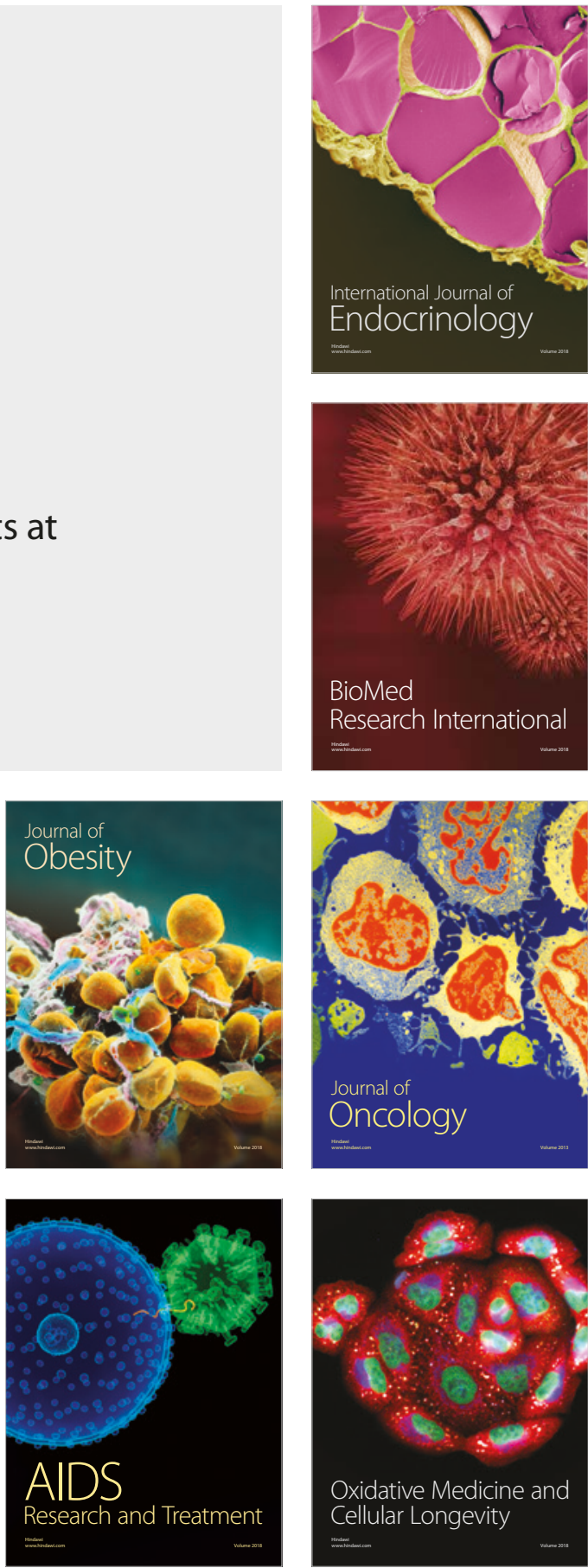